\title{
PULMONARY FUNCTION AND AEROBIC CAPACITY IN ASYMPTOMATIC BARIATRIC CANDIDATES WITH VERY SEVERE MORBID OBESITY
}

\author{
Joel Faintuch, Shirley A. F. Souza, Antonio C. Valezi, Antonio F. Sant'Anna and \\ Joaquim José Gama-Rodrigues
}

FAINTUCH J et al. Pulmonary function and aerobic capacity in asymptomatic bariatric candidates with very severe morbid obesity. Rev Hosp Clin Fac Med S Paulo 59(4):181-186, 2004.

PURPOSE: Aerobic capacity and respiratory function may be compromised in obesity, but few studies have been done in highly obese bariatric candidates. In a prospective study, these variables were documented in the preoperative period, aiming to define possible physiologic limitations in a apparently healthy and asymptomatic population.

METHOD: Forty-six consecutively enrolled adults (age $39.6 \pm 8.4$ years, $87.0 \%$ females, body mass index /BMI 49.6 $\pm 6.3 \mathrm{~kg} / \mathrm{m}^{2}$ ) were analyzed. Ventilatory variables were investigated by automated spirometry, aerobic capacity was estimated by a modified Bruce test in an ergometric treadmill, and body composition was determined by bioimpedance analysis.

RESULTS: Total fat was greatly increased $(46.4 \pm 4.6 \%$ of body weight) and body water reduced (47.3 $\pm 4.6 \%$ body weight), as expected for such obese group. Spirometric findings including forced vital capacity of $3.3 \pm 0.8 \mathrm{~L}$ and forced expiratory volume -1 second of $2.6 \pm 0.6 \mathrm{~L}$ were usually acceptable for age and gender, but mild restrictive pulmonary insufficiency was diagnosed in $20.9 \%$. Aerobic capacity was more markedly diminished, as reflected by very modest maximal time $(4.5 \pm 1.1 \mathrm{~min})$ and distance $(322 \pm 142 \mathrm{~m})$ along with proportionally elevated maximal oxygen consumption $(23.4 \pm 9.5 \mathrm{~mL} / \mathrm{kg} / \mathrm{min})$ achieved by these subjects during test exercise.

CONCLUSIONS: 1) Cardiopulmonary evaluation was feasible and well-tolerated in this severely obese population; 2) Mean spirometric variables were not diminished in this study, but part of the population displayed mild restrictive changes; 3) Exercise tolerance was very negatively influenced by obesity, resulting in reduced endurance and excessive metabolic cost for the treadmill run; 4) More attention to fitness and aerobic capacity is recommended for seriously obese bariatric candidates;

KEY WORDS: Morbid obesity. Bariatric operation. Aerobic capacity. Spirometry. Cardiopulmonary function.

Thirty years years ago, the most serious nutritional problem in the world and the source of multiple comorbidities was protein-calorie malnutrition, and it was considered a medical error to ignore protein and energy losses. ${ }^{1}$ A few decades later, the major disturbance of body composition in most latitudes is obesity, which is equally involved with myriads of comorbidities, and bariatric interventions are daily concerns. ${ }^{2}$ Would it be legitimate to recycle the old saying, re- iterating that no infirmity is known in which weight excess would be an advantage?

Certainly for pulmonary function this assumption would be appropriate, even though most obese persons ex-

From the Division of Surgery II, Hospital das Clínicas, Faculty of Medicine, University of São Paulo - São Paulo/SP, Brazil and the State University of Londrina - Londrina/ PR, Brazil.

E-mail: jfaintuch@ henet.usp.br Received for publication on January 01, 2004. hibit anatomically intact pulmonary structures. In fact, there are virtually no direct correlations between exessive energy or lipid intake and damage to trachea, bronchi, or alveoli. Contrarily, nowadays one often deals with a young and well-nourished population with an optimal intake of protein and essential nutrients for manufacture of specialized cells and tissues that is thus free from mucus deficits and immunologic aberrations often seen in protein-calorie malnutrition. ${ }^{3}$ How- 
ever, indirect negative influences of obesity abound, principally regarding distortions of respiratory spaces and dynamics.

Subjects with excessive body weight tend to be chronically hypoventilated and have reduced aerobic capacity, ${ }^{4}$ probably because of sedentarism as well as of a heavy thoracic wall and abdominal mass, and diminished compliance is a hindrance for safe mechanical ventilation during anesthesia and postoperative care. ${ }^{5}$ Both daytime and especially nocturnal neurophysiology may be impaired in association with obstructive sleep apnea. The tendency toward gastroesophageal reflux because of high intra-abdominal pressure along with hypoventilation may trigger various derangements; chronic bronchitis ${ }^{6}$ and asthma ${ }^{7,8}$ are not unusual; and after surgical operations, atelectasis is relatively common. ${ }^{9}$ Although asthma may be prominent in this setting and notably improves after bariatric treatment, ${ }^{7}$ respiratory insufficiency in the obese is mostly classified as restrictive. ${ }^{10}$

To those limitations one must add reduced cardiopulmonary ability as indicated by measurements of exercise tolerance and aerobic capacity. Morbidly obese people become easily dyspneic after moderate efforts such as moving up one flight of stairs or walking one city block. They tend to rely on exogenous means of transportation (elevators, escalators, cars, buses ), practically never run, and even avoid carrying weight such as shopping bags. These abnormalities have been confirmed by physiologic tests, during which a high metabolic cost for breathing, both at rest and after exercise, can be detected..$^{11,12}$

In spite of investigations concerning respiratory function in subjects with excessive adiposity, there is a scarcity of studies in advanced class III obesity or massive bariatric candidates including superobese subjects, and much controversy remains about their actual status.

Aiming to analyze relevant aerobic capacity changes and presence of ventilatory obstruction or restriction in this population, with a view both to anesthetic risks and tolerance of the surgical procedure as well as to future needs for physical rehabilitation, a protocol regarding spirometry and aerobic capacity was established for candidates for anti-obesity procedures.

\section{METHOD}

Patients accepted for bariatric treatment were consecutively enrolled in the study ( $n=46$ ), according to the following rules.

Criteria for inclusion:

- Males and females, age 18 to 60

- Body mass index $>40 \mathrm{~kg} / \mathrm{m}^{2}$, or $>35 \mathrm{~kg} / \mathrm{m}^{2}$ (with comorbidities)

- Body weight $<150 \mathrm{~kg} *$

- Informed consent Criteria for exclusion:

- Critical disease, shock, coma

- Acute myocardial infarction, cardiac arrhythmia, use of pacemaker

- Cardiac, respiratory, renal, or hepatic failure

- Senility, Alzhheimer's disease, or other dementias

- Bone/joint disease or chronic lymphedema interfering with treadmill test

- Difficulty in understanding instructions or lack of cooperation during tests

(*) Maximum weight capacity of treadmill

The following procedures were used in this study:

Questionnaire and physical examination: Patients were weighed, and height, blood pressure, and heart rate were measured. History of obesity, comorbidities, and other diseases were recorded, with emphasis on possible contraindications to the study.

Bioimpedance analysis (BIA): Body composition (body fat, fat-free mass, and total water) was estimated in the morning, after voiding, by the classic single frequency, tetrapolar technique (RJL BIA apparatus, Milton, Ill, USA).

Lung spirometry: A computerized spirometer was employed (Pony Spirometer Graphics- Cosmed, Rome, Italy) according to the guidelines of the American Thoracic Society (1991/ 1994) and the I Brazilian Consensus on Spirometry (1996) $)^{13-15}$. Documented variables included forced vital capacity (FVC), forced expiratory volume in 1 second $\left(\mathrm{FEV}_{1}\right)$, maximum voluntary ventilation (MVV), maximum midexpiratory flow at $25 \%$ and $50 \%$ (MMEF25\%/50\%), and the $\mathrm{FEV}_{1} / \mathrm{FVC}$ ratio.

Aerobic capacity: A modified Bruce test ${ }^{16}$ was applied with an ergometric treadmill, with emphasis on maximum speed, maximum heart rate, total distance, maximum $\mathrm{VO}_{2}$ consumption, and cardiorespiratory performance. Briefly, the 9 stages of the method corresponded to progressively greater efforts modulated by treadmill angle, at speeds of respectively 1.7 , $1.7,1.7,2.5,3.5,4.0,5.0,5.5$ and 6.0 miles/hour. At each step, maximum oxygen consumption ( $\left.\mathrm{VO}_{2} \max \right)$, heart rate, distance $(\mathrm{m})$, and time elapsed (min) were computed, and electrocardiographic tracings were continuously monitored. $\mathrm{VO}_{2} \max$ was derived from the formula $1.8 \mathrm{x}$ speed $\mathrm{x}(0.073$ + inclination degree/100).

The test was discontinued when subjects became tired with a given workload and a plateau of $\mathrm{VO}_{2}$ was perceived. The highest value for oxygen consumption was considered the subject's $\mathrm{VO}_{2}$ peak. 


\section{RESULTS}

All enrolled patients agreed to the study and successfully performed the tests. There were no exclusions or complications in this series. Results are shown as mean $\pm \mathrm{SD}$.

Preliminary findings: The mean age of the group was $39.6 \pm 8.4$ years $(25-57), 87.0 \%$ were females, and body mass index (BMI) was $49.6 \pm 6.3$ $\mathrm{kg} / \mathrm{m}^{2}(35.4-66.2)$. Despite the presence of 2 supersuperobese subjects in the series ( BMI $>60 \mathrm{~kg} / \mathrm{m}^{2}, 4.3 \%$ of the series) and 19 superobese (BMI> $50 \mathrm{~kg} / \mathrm{m}^{2}, 41.3 \%$ ), no case exceeded $150 \mathrm{~kg}$, which was the upper limit of acceptance for the ergometric treadmill.

Body composition: Body fat represented $46.4 \pm 4.6 \%$ of body weight, an abnormally high value that is entirely consistent with the substantial BMI figures previously indicated. Body water was proportionally depressed by the excess of adiposity (47.3 $\pm 4.6 \%$ body weight), and estimated metabolic rate supplied by the BIA apparatus was $2144 \pm 176 \mathrm{kcal} /$ day.

Lung spirometry: Forced vital capacity was $3.3 \pm 0.8 \mathrm{~L}$ and $\mathrm{FEV}_{1}$ reached $2.6 \pm 0.6 \mathrm{~L}$. Both values, as well as other ventilatory determinations, were usually within the expected range for seated adults in the appropriate age bracket. They corresponded to $96.5 \pm 27.8 \%$ and $103.0 \pm$ $26.4 \%$ respectively of the predicted finding. About $20.9 \%$ of the profiles fulfilled the requirements of mild restrictive pulmonary insufficiency, all others being classified as normal.

Aerobic capacity: The principal observations are listed in Table 1. Nearly all values were markedly diminished, and overall estimation of cardiopulmonary capacity was good in $8.7 \%$ (4/46), average in $23.9 \%$ (11/46), poor in $65.2 \%(30 / 46)$, and very poor in $2.1 \%(1 / 46)$.

Table 1 - Treadmill test (cardiopulmonary assessment).

\begin{tabular}{ll}
\hline Variable & Result \\
\hline Maximum time $(\mathrm{min})$ & $4.5 \pm 1.1$ \\
Maximum distance $(\mathrm{m})$ & $322 \pm 142$ \\
Maximum $\mathrm{VO}_{2}$ consumption $(\mathrm{mL} / \mathrm{kg} / \mathrm{min})$ & $23.4 \pm 9.5$ \\
\hline
\end{tabular}

\section{DISCUSSION}

Obesity may derange pulmonary function by virtue of its effects on ventilatory mechanics, on airway resistance, on pulmonary volumes, and on respiratory muscles. ${ }^{11,17,18}$

As total and abdominal fat increase, vital capacity (VC) and forced expiratory volume $\left(\mathrm{FEV}_{1}\right)$ are proportionally compromised. Furthermore, massive adipose accumulations in the thorax and abdomen interfere with pulmonary volumes and gas exchange, especially in the supine position. ${ }^{19,20}$

Resting oxygen consumption and $\mathrm{CO}_{2}$ production calculated for ideal body weight are increased in obese subjects because fat tissue has low but not negligible metabolic activity, lean body mass is elevated, and muscle groups involved with body movement are overworked in this heavy population. These alterations tend to disappear after anti-obesity therapy. ${ }^{21,22}$

In the present series, the mean age of the population was around 40 years, which reveals that it was not an elderly group and roughly corresponds to the age group typically seen for bariatric procedures. Nevertheless, the mean BMI was in the range of $50 \mathrm{~kg} /$ $\mathrm{m}^{2}$, which indicated extremely severe obesity. ${ }^{23}$ As anticipated, body fat came close to $50 \%$ of body weight, which is nearly $70 \%$ higher than the maximum recommended proportion for this population, despite the suspicion that bioimpedance analysis underestimates body fat in morbidly obese children and adults. ${ }^{24}$ By the same token, body water was diminished (less than the usual $50 \%$ to $55 \%$ ), not because there were signs of dehydration, but as a consequence of exaggerated adiposity, with a reduced relative contribution of water-rich lean body mass to actual weight. $4,5,25$

Forced vital capacity (FVC) and forced expiratory volume in 1 second $\left(\mathrm{FEV}_{1}\right)$ were basically well conserved in the study group, despite serious changes in body composition and consequently in thoraco-abdominal anatomy. Indeed, surgical candidates are usually screened for heavy smoking, chronic bronchitis, asthma, pulmonary hypertension, and other serious respiratory conditions that might increase anesthetic risk. Therefore, notwithstanding the fact that there were many superobese (BMI $>50 \mathrm{~kg} / \mathrm{m}^{2}$ ) and even supersuperobese patients (BMI $\left.>60 \mathrm{~kg} / \mathrm{m}^{2}\right)^{5,21}$ in this study, negative impacts on lung physiology could not be demonstrated.

It is generally accepted that as body weight increases, respiratory compliance diminishes in the same proportion, with reductions up to $30 \%$ in advanced situations. Low compliance is associated with reduced forced vital capacity and gaseous exchange. Within this context, a pattern of rapid and shallow respiratory movements may ensue, which limits maximal ventilation and exacts a higher cost of respiratory work..$^{19,21}$

The most reported pulmonary function test abnormalities in obesity are reduced expiratory reserve volume (ERV) and functional residual capacity (FRC) due to alterations in chest wall mechanics, which also lead to decreased total respiratory compliance. ${ }^{26}$ After weight loss, increases in functional residual capacity, residual volume, total lung capacity, and expira- 
tory reserve volume tend to restore ventilatory normality. ${ }^{21}$

In the current study, restrictive transformations were demonstrated in $20.9 \%$ of the candidates, although a larger impact on lung physiology would not have been inappropriate in such high-BMI population.

The modified Bruce test revealed more serious shortcomings. Patients ran modest distances and became tired shortly after the start of the treadmill procedure, and yet they paid a steep metabolic price in the form of $\mathrm{O}_{2}$ consumption. For many years, it has been noticed that endurance is restricted in the presence of excessive body weight, subjects become quickly exhausted, and energy cost is excessive, reflecting poor cardiopulmonary performance along with the effects of a chronically sedentary lifestyle..$^{25}$

Indeed, the intensity of the test should be carefully tailored to not overwork the cardiocirculatory system, and constant electrocardiographic monitoring as was performed in this study is advised, because structural distortions of the myocardial muscle and heart vessels are not uncommon in this population. ${ }^{27-29}$

In the present series, no side effects of the modified Bruce test were noticed, and all patients tolerated the exercise very well, despite their substantially altered body composition. Highrisk subjects with arterial hypertension, congestive heart failure, myocardial ischemia, or respiratory insufficiency were obviously eliminated due to the exclusion criteria and thorough preliminary assessment, and subjects were instructed to run only as long as they felt comfortable, avoiding any strenuous efforts.

Nevertheless, it has been reported that multiple comorbidities and physical dysfunctions, including skin friction, urinary stress incontinence, varicose veins, knee and foot deformity or pain, and chronic arthritis of spine or hip joints hamper the successful completion of walk and run tests in the context of obesity. ${ }^{3}$ Again, careful observation of contraindications assured a trouble-free protocol.

These morbidly obese individuals, even though displaying nominally good health, being asymptomatic and having passed all steps of preoperative screening, were effectively proven to be handicapped persons. They can be considered natural candidates for specialized physical guidance, especially when selected for operation, for several reasons including to enhance recovery and prevent perioperative complications, such as pneumonia and atelectasis, 5,6 and also to promote fitness and improved quality of life coincident with postoperative weight loss.

Analysis of therapeutic exercising and physiologic rehabilitation was not among the aims of this diagnostic study; therefore, no conclusions can be presented regarding results of such interventions. Some studies suggest that most deranged parameters improve in the late postoperative period after a more normal body composition has been achieved, even without deliberate exercise. ${ }^{17,18}$

Although few specific references to bariatric candidates could be identified in the literature, it is reasonable to propose that more encouraging outcomes would be elicited if progressive physical conditioning were offered to this population jointly with surgical therapy. ${ }^{26-30}$

\section{CONCLUSIONS}

It is concluded that:

1) Cardiopulmonary evaluation was feasible and well tolerated in this severely obese population;

2) Mean spirometric variables were not diminished in this study, but part of the population displayed early restrictive changes;

3) Exercise tolerance was very negatively influenced by obesity, resulting in reduced endurance and excessive metabolic cost for the treadmill run;

4) More attention to fitness and aerobic capacity is recommended for seriously obese bariatric candidates.

\section{RESUMO}

FAINTUCH J e col. Função pulmonar e capacidade aeróbica em candidatos bariátricos assintomáticos com obesidade mórbida muito avançada. Rev Hosp Clin Fac Med S Paulo 59(4):181-186, 2004.

OBJETIVOS: A capacidade aeróbica e a função respiratória podem estar comprometidas na obesidade mórbida, todavia poucos estudos são disponíveis em candidatos à cirurgia bariátrica com massa corporal muito elevada.Num protocolo prospectivo, estas variáveis foram documentadas no pré-operatório, visando despistar possíveis limitações fisiológicas numa população nominalmente sadia e sem queixas.
MÉTODO: Foram analisados 46 casos consecutivos (idade $39.6 \pm 8.4$ anos, $87.0 \%$ mulheres, índice de massa corporal /IMC $49.6 \pm 6.3 \mathrm{~kg} / \mathrm{m} 2$ )) As variáveis ventilatórias foram investigadas por espirometria automatizada e a capacidade aeróbica mediante um teste de Bruce modificado em esteira ergométrica, sendo que a composição 
corpórea foi fornecida pela bioimpedância.

RESULTADOS: A gordural total estava fortemente aumentada (46.4 \pm $4.6 \%$ do peso) e a água corporal diminuída $(47.3 \pm 4.6 \%$ do peso) nesta série, tal como esperado para o grau de obesidade descrito. Os achados espirométricos médios incluindo-se capacidade vital forçada de $3.3 \pm 0.8 \mathrm{~L} \mathrm{e}$ volume expiratório forçado de 1 segundo de $2.6 \pm 0.6 \mathrm{~L}$ não fugiram do aceitável para idade e sexo. Entretanto em $20,9 \%$ insuficiência respiratória restritiva leve foi diagnosticada. A capacidade aeróbica estava mais nitidamente prejudicada, seja pelo baixo tempo e distância máxima atingidos (respectivamente $4.5 \pm 1.1 \mathrm{~min}$ e 322 $\pm 142 \mathrm{~m}$ ), seja pelo custo proporcionalmente alto do esforço, refletido pelo consumo máximo de oxigênio (23.4 \pm $9.5 \mathrm{ml} / \mathrm{kg} / \mathrm{min})$;

CONCLUSÕES: 1) A avaliação cárdio-respiratória foi factível e bem tolerada; 2) As variáveis espirométricas méias não estavam alteradas, porém parte da população exibiu trans- formações restritivas leves; 3) A obesidade interferiu negativamente sobre a tolerância ao exercício, reduzindo o desempenho e aumentando o custo metabólico da corrida em esteira ergométrica; 4) Recomenda-se maior atenção à capacidade aeróbica de candidatos bariátricos seriamente obesos;

UNITERMOS: Obesidade mórbida. Operação bariátrica. Capacidade aeróbica. Espirometria. Função cardiopulmonar.

\section{REFERENCES}

1. Faintuch J, Machado MCC, Raia AA. Alimentação parenteral prolongada, São Paulo, Manole, 1976.

2. Faintuch J. Mensagem. Boletim da SBNPE 2001;6(36):3.

3. Reyes MA, Saravia NG, Watson RR, McMurray DN. Effect of moderate malnutrition on immediate hypersensitivity and immunoglobulin E levels in asthmatic children. J Allergy Clin Immunol 1982;70:94-100.

4. Hulens M, Vansant G, Claessens AL, Lysens R, Muls E. Predictors of 6-minute walk test results in lean, obese and morbidly obese women. Scand J Med Sci Sports 2003;13:98-105.

5. Ogunnaike BO, Jones SB, Jones DB, Provost D, Whitten CW. Anesthetic considerations for bariatric surgery. Anesth Analg 2002;95:1793-805

6. Guerra S, Sherrill DL, Bobadilla A, Martinez FD, Barbee RA. The relation of body mass index to asthma, chronic bronchitis, and emphysema. Chest 2002;122:1256-63.

7. Dixon JB, Chapman L, O’Brien P. Marked improvement in asthma after Lap-Band surgery for morbid obesity. Obes Surg 1999;9:385-9.

8. Ben-Noun L. Characteristics of comorbidity in adult asthma. Public Health Rev 2001;29:49-61.

9. Eichenberger A, Proietti S, Wicky S, Frascarolo P, Suter M, Spahn DR, et al. Morbid obesity and postoperative pulmonary atelectasis: an underestimated problem. Anesth Analg 2002;95:1788-92.

10. Joris JL, Sottiaux TM, Chiche JD, Desaive CJ, Lamy ML. Effect of bi-level positive airway pressure (BiPAP) nasal ventilation on the postoperative pulmonary restrictive syndrome in obese patients undergoing gastroplasty. Chest 1997;111:665-70.

11. Gibson GJ. Obesity, respiratory function and breathlessness. Thorax 2000:55(Supp1 1):S41-S44
12. Kress JP, Pohlman AS, Alverdy J. The impact of morbid obesity on oxygen cost of breathing ( $\mathrm{VO}_{2} \mathrm{RESP}$ ) at rest. Am J Resp Crit Care Med 1999;160:883-6.

13. American Thoracic Society. Lung function test: selection of reference values and interpretative strategies. Am Rev Respir Dis 1991;144:1202-18.

14. Neder JA, Andreoli S, Castelo-Filho A. Reference values for lung function tests. I. Static volumes. Braz J Med Biol Res 1999:32:703-17.

15. Brazilian Society of Pneumology and Physiology (SBPT). I Brazilian Consensus on Spirometry. J Pneumol 1996;22:10564.

16. Bruce RA, Kusumi F, Hosmer D. Maximal oxygen intake and nomographic assessment of funcional aerobic impairment in cardiovascular disease. Am Heart J 1973;85:546-62.

17. Koenig SM. Pulmonary complications of obesity. Am J Med Sci 2001;321:249-79.

18. Alpert MA. Cardiovascular and pulmonary complications of obesity: An overview. Am J Med Sci 2001;321:213-4.

19. Lazarus R, Gore CJ, Booth M. Effects of body composition and fat distribution on ventilatory function in adults. Am J Clin Nutr 1998;68:35-41.

20. Kelly TM, Jensen RL, Elliott CG. Maximum respiratory pressures in morbidly obese subjects. Respiration 1988;54:73-7.

21. Thomas PS, Cowen ER, Hulands G, Milledge JS. Respiratory function in the morbidly obese before and after weight loss. Thorax 1989;44:382-6.

22. Refsum HE, Holter PH, Lovig T, Haffner JF, Stadaas JO. Pulmonary function and energy expenditure after marked weight loss in obese women: Observations before and one year after gastric banding. Int J Obes 1989;14:175-83. 
Pulmonary function and aerobic capacity in asymptomatic bariatric Faintuch $\mathrm{J}$ et al.

23. Faintuch J, Rudner MA, Machado PLRC et al. - Influence of bariatric surgery on comorbidities and complications. Obes Surg 2002; 12:486.

24. Leme RBA, Froes MS, Faintuch J, et al - Difficulties in the assessment of body composition in obese children. Clin Nutr 2002; 21(Supp1 1):82.

25. Souza MSF, Cardoso AL, Yasbek JR P, et al. Aerobic endurance, energy expenditure and leptin response in obese sedentary prepubertal children submitted to a short-term treadmill protocol. Nutrition 2004 (In press).

26. Sahebjami H, Gartside PS. Pulmonary function in obese subjects with a normal FEV,/FVC ratio. Chest 1996;110:1425-9.

27. Donnelly JE, Jacobsen DJ, Heelan KS, Seip R, Smith S. The effects of 18 months of intermittent vs. continuous exercise on aerobic capacity, body weight and composition, and metabolic fitness in previously sedentary, moderately obese females. Int J Obes Relat Metab Disord 2000;24:566-72.
REV. HOSP. CLÍN. FAC. MED. S. PAULO 59(4):181-186, 2004

28. van Aggel-Leijssen DP, Saris WH, Wagenmakers AJ, Senden JM, van Baak MA. Effect of exercise training at different intensities on fat metabolism of obese men. J Appl Physiol 2002;92:13009.

29. Jakicic JM, Donnelly JE, Pronk NP, Jawad AF, Jacobsen DJ. Prescription of exercise intensity for the obese patient: the relationship between heart rate, $\mathrm{VO}_{2}$ and perceived exertion. Int J Obes Relat Metab Disord 1995;19:382-7.

30. Alpert MA, Terry BE, Kelly DL. Effect of weight loss on cardiac chamber size, wall thickness and left ventricular function in morbid obesity. Am J Cardiol 1985;55:783-6. 